\title{
HISTORY DISCOURSES AND RECONCILIATION PROCESS IN POST-SUHARTO INDONESIA
}

\begin{abstract}
After periods of internal conflicts and authoritarianism, educational institutions often have to be reformed. However, in countries where education has been used to support repressive politics and violations of human rights, or when conflicts and abuse have resulted in a loss of educational opportunities, a traumatic past and the legacy of injustice can be a serious challenge to effective educational reforms. Prospects for the development of democracy, which usually fuel the program of rebuilding the state and building a civil society, do not often attach great importance to the settlement of the brutal past in historical education. Meanwhile, the coupling of transitional justice and reform of education systems, including historical education programs, can facilitate the reintegration of society, including children and youth in the society, and may involve younger generations in work for justice.

The history of 1965-66 in Indonesia, the history of mass killings and the imprisonment of hundreds of thousands of alleged communist Indonesians, was for a long time silenced and mystified by anti-communist mythology. This was created by the authoritarian rule of Suharto. This article examines how the Orde Baru constructed a strong policy of remembrance and how this narrative that labels victims as perpetrators deserving their fate dominated historical politics (history education). This approach is still present in the official historical and political narrative in Indonesia. Meanwhile, showing the history of victims in the history education can be a prerequisite for understanding the process of reconciliation by Indonesians, thus having an impact on the democratisation of society. Thus, historical education is closely connected with transitional justice.
\end{abstract}

Key words: Indonesia; 1965-66 massacres; transitional justice; reconciliation; history education; New Order; collective memory
KATARZYNA MARTA GŁAB SWPS Uniwersytet Humanistycznospołeczny, Warszawa E-mail: kglab@swps.edu.pl

CITATION: Głąb, K. M. (2018). History Discourses and Reconciliation Process in Post-Suharto Indonesia. Sprawy Narodowościowe. Seria nowa, 2018(50). https://doi.org/10.11649/sn.1648

This work was supported by the author's own resources. No competing interests have been declared.

This is an Open Access article distributed under the terms of the Creative Commons Attribution 3.0 PL License (creativecommons.org/licenses/by/3.0/pl/), which permits redistribution, commercial and non-commercial, provided that the article is properly cited. (C) The Author(s) 2018.

Publisher: Institute of Slavic Studies, Polish Academy of Sciences 


\section{DYSKURSY HISTORYCZNE A PROCES POJEDNANIA W INDONEZJI PO EPOCE SUHARTO}

\section{Streszczenie}

Dyskursy historyczne wiążą się ściśle z pojednaniem w procesie sprawiedliwości okresu przejściowego. Po okresach wewnętrznych konfliktów i autorytaryzmu, instytucje edukacyjne często muszą zostać zreformowane. Jednak w krajach, w których edukacja została wykorzystana do wspierania represyjnej polityki i łamania praw człowieka, traumatyczna przeszłość i spuścizna niesprawiedliwości mogą stanowić poważne wyzwanie dla skutecznych reform edukacyjnych, a tym samym demokracji.

W artykule przeanalizowano, w jaki sposób Nowy Ład generała Suharto skonstruował silną politykę pamięci, i jak oficjalna narracja historyczna, określająca ofiary jako sprawców zasługujących na swój los, zdominowała politykę historyczną (edukację historyczną). Badanie pokazało, w jaki sposób to podejście jest nadal obecne w oficjalnej historycznej i politycznej narracji w Indonezji. Tymczasem pokazanie historii ofiar terroru w edukacji historycznej może być warunkiem wstępnym zrozumienia procesu pojednania przez Indonezyjczyków, a tym samym wpływania na demokratyzację społeczeństwa. W ten sposób edukacja historyczna jest ściśle związana ze sprawiedliwością okresu przejściowego.

Słowa kluczowe: Indonezja 1965; sprawiedliwość okresu przejściowego; edukacja historyczna; pamięć zbiorowa; Nowy Ład; Suharto

\section{INTRODUCTION}

A t the turn of 1965 and 1966, in just a few months, the regime of General Suharto murdered about a million people, and perhaps many more. In terms of the number of people killed and the way it happened, the anti-communist massacres qualify, next to the Soviet purges, Nazi murders or bloody Maoist governments, as the largest genocides of the 20th century (see Cribb, 1990). The victims were members of the Communist Party of Indonesia (Partai Komunis Indonesia, PKI), people suspected of favouring the communists and the Chinese minority (automatically included in any of the previous groups). Many millions of Indonesians have been unjustly imprisoned and have been in tragic conditions in prisons and labour camps for many years. The extermination of the communists affected not only the situation and the distribution of political forces in the Asian region, but it was also of great importance on a global scale, in the context of the Cold War confrontation of the great powers. During the peak period of the Cold War, the mass murders have been perceived by the Western world as a victory over communism.

The trigger of these events was an unsuccessful attempt. Facts that could be determined are partly unclear and do not necessarily constitute a logical whole. We know with certainty that on the night of September 30, 1965, six high-ranking generals were abducted. They were taken to a place called Lubang Buaya, located on the outskirts of Jakarta, and killed there. In the morning of October 1, the abductors announced that the power in the country was temporarily taken over by the "30 September Movement" (Gerakan 30 September, G30S) to prevent a coup being prepared by a US-backed group of generals. A few hours later, all participants in the movement were arrested by General Suharto. It was announced at the time that the PKI was responsible for the attack.

Who were the real attackers? To this day, there is no certainty, and only some hypotheses exist (Zurbuchen, 2002, p. 566). What is certain, however, is that the military regime began a profound change in the political, social, economic and cultural life of Indo- 
nesia, whose effects are still visible today. The attack began the reign of Orde Baru (New Order of General Suharto), which lasted continuously until 1998. For more than three decades, the regime ruled using strong military repression, brutally suppressing many violent conflicts behind the propaganda screen of stability and security.

There is a temptation to see quite simply the strong authoritarianism in static and totalizing terms, in which the ruling agency exercises power through all-embracing coercion and systematic terror. Therefore, in the same way, it is easy to imagine the end of authoritarianism as the removal of these pathological elements from public life. The basic assumptions of authoritarianism were based on mass violence from 1965-66, which was the most important element in shaping the national identity, imagination and daily activity of millions of people, forming the fourth most populated country in the world. This very past is a decisive factor in socio-political life until today (Heryanto, 1999).

In this article, I examine how the Orde Baru constructed a strong policy of remembrance and how it dominated historical politics, which is still present in the official historical and political narrative in Indonesia. I would like to outline the problems of history education in Indonesia, and I will also bring closer its importance in the transitional justice (TJ) process as increasing the chances of success in the reconciliation process. The history curriculum in schools is extremely important in the context of dealing with the difficult past. The issue of developing a new core curriculum is overlooked as a great challenge for the current government and seen as potentially conflictogenic. I will argue that the lack of prospects of victims in the history taught in public education causes difficulties in understanding the process of reconciliation by Indonesians, thus having an impact on the ongoing deprivation of innocent people. This article is not, of course, an exhaustive examination of all strategies and aspects of TJ in Indonesia.

\section{CONSTRUCTING AND CONTROLLING COLLECTIVE MEMORY OBLIVION}

To this day in Indonesia, silent survivors, murderers and witnesses live next to each other. The past trauma has survived and functions basically in an unchanged form. Over the years, after the assassination, various versions of these events as the same "communist threat" led their own lives, at the same time effectively shifting public opinion away from the mass murders that followed the coup. The continuing strong regime meant that the survivors of the massacres could only speak in the few moments when the hegemonic discourse was weakened. The past killings are basically still unspoken, in the silent past, more and more in the spiritual as well as the material sphere. In public circulation, the version of the coup created by the Suharto regime is still in force, and in the private sphere also parents and grandparents reluctantly talk about what they have seen or directly experienced. According to Heryanto, this is not only related to obvious official censorship or fear of repression. The problem is the lack of a ready discourse regarding the structure and narrative of such a traumatic past (Heryanto, 1999, p. 152).

Throughout the Orde Baru years, school textbooks had to strictly follow the imposed version of events. Speaking of Gerakan September Tiga Puluh, the acronym Gestapu was deliberately used. It was associated with the secret police of the Third Reich and create a terrifying aura around the G30S (Roosa, 2010). The detailed descriptions of the tortures which the generals were allegedly subjected to before their death had an effect on the imaginations of the masses. Their eyes were to be plucked, and the genitals were cut off 
by activists of the Indonesian Women Movement (Gerakan Wanita Indonesia, GERWANI), associated with PKI. During the torture and mutilation of generals, "communist ideology followers" allegedly danced naked and sang "Genjer, Genjer" (Roosa, 2006, p. 6). The army fabricated many such "facts" during the campaign against the PKI.

This prepared story has been pressed into the consciousness of Indonesian society for years through all available media: radio, press, cinema, school textbooks and celebrated during national holidays. In "The Look of Silence", the teacher tells the children during a history lesson: "Imagine how it hurts if your eyes were plucked out. They had cut their eyes! If you get chicken and cut off his head... Is it not cruel? The Communists were cruel, so the government had to stop them. That's why we should thank the heroes who fought to make our country democratic" (Roosa \& Oppenheimer, 2014). Murderers reconstructing their crimes in "The Act of Killing", still live in such an official narrative (Oppenheimer, 2012). On the one hand, they have a set of official facts existing in the social consciousness for several decades, on the other, they are convinced of their heroism, strengthened by collective lies of the regime currently in force, being nothing but the history of the winners. As Joshua Oppenheimer notes, there is no contradiction between what they know and what they believe in Roosa and Oppenheimer (2014).

The main institution responsible for shaping the policy of remembrance was Armed Forces History Center (Kepala Pusat Sejarah ABRI), built in 1964 to create and preach its own interpretation of the history of the nation. Within two months after the coup, as ordered by $A B R I$, the team of General Nugroho Notosusanto (later Education Minister) has written the book "40 Hari Kegagalan G30S 1 Oktober-10 November" ("40 days of the September 30 defeat"), establishing indisputable dogmas, repeated after decades (McGregor, 2007, p. 39). The Suharto regime, creating a new history of the nation, has removed everyone else from the official narrative circle ${ }^{1}$, thus constructing the collective memory of the nation.

"Truth is the first victim of any repressive regime" (Davies, 2017, p. 334). From the very first days, $A B R I$ unleashed a public PKI campaign in the media, portraying it as the embodiment of pure evil, the power of darkness and chaos. The coup was widely spoken of as a violent assault on the government and the state. Sukarno was placed under house arrest, and the army arrested thousands of PKI activists. They were given an enigmatically sounding accusation: "direct or indirect involvement in the G30S". The word "indirect" was understood very broadly. It was a sufficient justification to arrest anyone who had any contact with PKI. In case of any doubts, interpretation had to be made to the "benefit of the nation". Any person under any suspicion would be destroyed. The CIA helped considerably in the creation of the "death lists"2 (Vickers, 2005). The American media celebrated the Indonesian upheaval as a "historic turning point" (Simons, 2000, p. 178).

The army aimed to involve the majority of the society in the fight. First of all, to increase the legitimacy of their actions, secondly, to lead to a great social uprising. Thus, $A B R I$ increased the role of society, and decreased its own, in anti-Communist incidents taking on momentum (see Robinson, 2017).

The vision of Suharto's attack was additionally promoted by the film "Pengkhianatan G30S/PKI" from 1983 ("The Treachery of the G30S/PKI"), in which the most important figure is Suharto himself, the saviour of the nation. The film was screened at public

The most famous writer whose works were inscribed on the blacklist was Pramoedya Ananta Toer, imprisoned for 14 years (1965-1979).

2 It is no secret that the US and the UK, which conduct a strong anti-communist policy, more or less expressed their approval in relation to Suharto's actions. 
schools and on TVRI public television, on 1 October each year, from 1984 to 1997. In the year of the overthrow of Suharto, the film was not shown. It is a monumental propaganda super-production lasting almost four hours, with the stars of Indonesian cinema, directed by one of the most outstanding Indonesian directors, Arifin C. Noer. It is exaggerated, full of dramatic and drastic scenes and uses very shallow emotional grips. However, it is perfectly understandable for the Indonesian viewer. It shows noble generals just before the attack, staying in their warm family homes, in which loving wives take care of them, and children sleep peacefully in their beds. PKI members preparing for the attack are presented like mafia members, criminals who plan their crime in the cigarette smoke.

Ade Mardiyati, the editor of the portal Ingat '65, remembers how she watched this film every year with her sister and brother, and then did her homework for school, i.e. wrote raport from the film. "As a good student, I always wrote the same script, showing how Suharto saved the nation from destruction. If I knew then that behind Suharto's heroic stories there are suffering and violence, maybe my report that I wrote would be different" (Mardiyati, 2017). Paradoxically, today, in her own way, she misses watching the film, for its uniting force during family watching, causing fear caused by the terrifying story to become bearable.

The undefined and inaccessible phenomenon of mass murder was used by the regime to justify the complicated political and cultural control structure in the state and restrictions on specific social groups. The alleged bad intentions of the PKI were also used to justify the persistent and vengeful persecution of Indonesians who were associated with the left who survived the massacre. Over one million people were placed in concentration and labour camps. Some of them were in camps for ten years or even longer (Cribb \& Ford, 2010). About 250,000 people have been removed from society and transported to seclusion. They remained there without trial and judgment until 1979 (Taylor, 2003).

After being released from prisons and camps, in the face of the continuing depravity of civil rights of "communists" in Indonesia and the civil rights of their family members, former prisoners had to bear with everyday persecution and ubiquitous restrictions as a murderers. In identity documents they had a special "ET" mark from Eks-Tahanan-politik, "a former political prisoner" (Heryanto, 2006, p. 17). They remained under the close supervision of the authorities. They were under house arrest or had to regularly appear in local military headquarters. At every step, they met with the disapproval of the society. They were forbidden to work in offices. Their children faced the similar fate, even if they were born long after 1965. Many of this generation, growing up after Indonesia has become independent, the most talented scientists, teachers, artists, journalists and natural social leaders, have been killed or treated as a superfluous, hostile element (Vickers, 2005, p. 160).

Still, the largest "monument" of the Suharto regime is the existing museum complex in Lubang Buaya, which is a lieu de memoire within the meaning of Pierre Nora (Schreiner, 2005). The birthplace of Suharto's regime is a secret and "sacred" place for every Indonesian, hidden from tourists, to which they have been constantly brought as "pilgrims" since 1965, in order to shape their worldview, build a civic identity and enable them to parcitipate in the intimate experience of their nation's past (Głąb, 2017). In Suharto's time, this place was an obligatory destination for primary school classes from Java, but today it is by no means a "dead" place.

The ubiquity of the anti-PKI myth and how it was constructed causes PKI members, their descendants, and all suspects of communist beliefs to become a demonic collectivity, treated as a separate ethnic group who, guilty of crimes against the state, should 
always be eliminated. In Indonesia, ethnicity is deeply internalised as something hereditary, natural and inseparable (Heryanto, 2006, p. 34), and that is why the Communist virus is transmitted from generation to generation like original sin. Not only victims of events (guilty) are contaminated, but also their descendants who are related to them by blood. In this situation, the only thing that victims can feel is shame imprinted in their consciousness from the moment they were born.

\section{DIFFICULT WAY TO RECOVER MEMORY}

The violent transformation in the state-following the armed conflict or the fall of authoritarian rule-is accompanied by TJ. Its purpose is to disclose and account for crimes against humanity committed as a result of depriving one or several social groups of dignity and rights, including, above all, the right to existence. Using legal and non-legal means, it is to build (or rebuild) a stable civil society and a stable state. This is not possible without restoring ethical order. Traumatic past, truth and reconciliation commissions (TRC), material or symbolic compensation programs, structural and systemic reforms in the field of constitutionality, lustration, actions aimed at establishing and revealing the truth about past crimes, making archives and sources available, conducting historical and policy policies that serve to "work through" the traumatic past creating a culture of memory. The main means of settling the nation's traumatic past is lawmaking, as well as history education in education, the construction of memorial sites and museum education. It is essential that the created collective and individual identity is not based on the process of repression of dirt, impurities and waste of history, but on truth and forgiveness.

The investigation into the truth about mass crimes has only been possible since the collapse of the Suharto regime, i.e. since 1998. This time is referred to as Reformasi. A positive effect is the appearance of many new publications that deal with these dramatic events while contributing to their clarification. On the other hand, after fifty years of genocide, many traces of crime have already been obliterated and evidence of crimes destroyed. Despite the formal freedom of speech in Indonesia, the slaughter of communists is still a sensitive topic and, in principle, is not a subject of nationwide public debate. Witnesses usually prefer to be silent rather than to expose themselves to unpredictable consequences. It would seem that authoritarianism will leave with Suharto, and the end of the rhetoric of the "threat of communism" is inevitable. Nothing could be more wrong. Since the fall of the regime and when the systemic change began in Indonesia, some actions have been taken to investigate the crimes of 1965, but it is difficult to speak of any coherent and developed policy of remembrance.

In the first years after the fall of the regime, there was indeed an unprecedented "explosion of interest" in the context of events from 1965-66 and other state-sponsored crimes. The room for discussion was opened. Numerous organisations were formed, and their goal was to collect testimonies of people who experienced the cruelty of the regime in order to break the hegemonic narrative of the Orde Baru and point out those responsible for the violence ${ }^{3}$. These organisations have collected thousands of survivor

3 Among the most notable are Syarikat (the Islamic Society for People's Advocacy, Yogyakarta) and the YPKP65 (Foundation for Research into Victims of the 1965-1966 Killings, Jakarta). 
testimonies in the last twenty years (Pohlman, 2013, 2016; Wahyuningroem, 2013). They also partly succeeded in carrying out an exhumation of mass graves in Java ${ }^{4}$ (McGregor, 2012). They often actively cooperate with each other, creating larger coalitions of non -government and victims advocacy organisations. Their activities are in contrast to the unsuccessful official actions of the national bodies for the protection of human rights, institutions set up by the government, which were to explain the traumatic past. It is primarily about defunct TRC legislation and the non-apologies for the 1965-1966 massacres and other attitudes. Susilo Bambang Yudhoyono $(\mathrm{SBY})^{5}$ and the current President, Joko (Jokowi) Widodo6 (Pohlman, 2016, p. 61).

The memory recovery process is very tedious. None of the five presidents in power in Indonesia after the fall of Suharto in 1998 made settlements with the past a priority, and the mass murders of 1965 are not the only crime of the Orde Baru. The presidency of Abdurrahman Wahid (1999-2001), the liberal former head of the influential Islamic organisation Nahdlatul Ulama (NU), introduced hope for a genuine reconciliation process, a historical investigation, rehabilitation of victims and their families, and prosecution of the perpetrators of the massacres. Wahid personally appealed for the disclosure of the truth, and even asked for forgiveness for the participation of his NU organisation in the massacres of 1965-66 (Fealy \& McGregor, 2012), and also called for the cessation of persecution. Many people hoped that the reconciliation would begin, including the recovery of bodies and the possibility of performing funeral ceremonies for those who had not yet been buried, thereby launching the mourning that would allow them to work through the loss. Wahid's apology, however, caused serious controversy in the Islamic community in Indonesia. As a result, he was isolated.

In 2012, the National Human Rights Commission of Indonesia (Komnas HAM) investigated the crimes committed and stated that they constitute systematic and widespread crimes against humanity. Komnas HAM recommended that the prosecutor general continues the criminal investigation, establish an ad hoc court for human rights in order to prosecute the perpetrators and establish an out-of-court truth and reconciliation commission, as already provided for in Law 26/2000 on the Court of Human Rights. Komnas HAM's report was rejected by the prosecutor general, with the argument that its findings were not legally sufficient.

Only after several dozen years, the symposium, where two groups met: representing the victims and representing power, took place in Jakarta on 18-19 April 2016, for the first time after the tragic events of 1965 (Karmini \& Wright, 2016). It can be called a very small step towards a public debate about massacres and justice for victims (Topsfield \& Rompies, 2016). Unfortunately, the government of Jokowi did not take any further action. And, Luhut Pandjaitan, Coordinating Minister for Politics, Law, and Security, in his Opening Remarks to this National Symposium on the 1965 Tragedy, has said: "We will not apologise. We are not that stupid. We know what we did, and it was the right thing to do for the nation" (Melvin, 2016).

\section{-....}

4 A mass grave in Central Java was exhumed in November 2000, and the documentary film of the event circulated online.

5 President SBY reportedly drafted a text to apologise to the 1965 victims on his National Day speech of 17 August 2012, but he was dissuaded. Two days before his address, a demonstrative meeting of Islamic leaders and retired generals led by the vice-chairman of NU said it was best to forget the 1965 issue (see: Santoso \& van Klinken, 2017, p. 595).

6 Jokowi promised before his 2014 election to resolve 1965 and other state-sponsored crimes, but since then almost nothing was done to overcome resistance among the military figures who support him (see for example Aritonang, 2017). 
It was similar to the verdict of the International People's Tribunal 1965. The IPT 1965 has been working since 2013, and as of September 2015 the proposed research results where collected and legally formulated so that they could be presented to the panel of judges. Hearings were held 10-13 November 2015 in The Hague. In Final Report from July 20, 2016, it was clearly stated that Indonesia is responsible for the murder of civilians and the use of torture with exceptional cruelty, and the government should apologise, start investigating and punishing people who took part in purges from many years ago. In addition, Australia, the USA and the UK took part in the events in Indonesia using propaganda to manipulate the international community in favour of Suharto and his army. Western states not only supported the overthrow of the first Indonesian president Sukarno, but also distorted the real picture of the situation that took place in Indonesia, allowing for further repression. The government stated that it had no intention of apologising, and the states accused of complicity had ignored the verdict.

We observe, therefore, the impasse in the reconciliation process in Indonesia. Scholars and activists point to the complete failure of subsequent government administrations since the end of the Suharto regime with regard to efforts to cope with past violations of human rights and to encourage reconciliation. Many of them point to the current ingrained culture of impunity and the fact that Indonesia is an example of how the new governments give up all attempts to restore justice in return for the short-term goals of securing elites' support for democratisation. However, the price of this support is too high: poor quality democracy, the takeover of newly built democratic institutions by oligarchic elites and the withdrawal from difficult reforms for human rights (Polhman, 2016, p. 61).

\section{HISTORY EDUCATION IN THE TRANSITIONAL JUSTICE IN INDONESIA}

The reconciliation faces numerous obstacles also in the society itself. The biggest among them was and still is the disagreement of the general public to discover the inconvenient truth or the usual lack of interest on the part of Indonesians. Public knowledge of what happened in 1965 is minimal. The very history of the attack is a problem in itself. Three Indonesians staying in Poland (all in the 35-40 age group) with whom I talked about the events of September 30, gave me three different theories about who was behind the attack and each of them was absolutely convinced that their theories are justified. However, none of them mentioned anything about Suharto's bloody revenge on millions of innocent citizens.

This is not surprising if you consider the gap in history education. In practice, most of those who feel the need to learn about these dramatic events reach for limited circulation and hard-to-find publications, often showing different interpretations of the coup and the period following it. Teachers are not authorised to determine the truth of these various historical relationships, and are often overwhelmed by the students' questions. Regardless of what students learn from various sources outside of school, exam answers still refer to the "truth" defined by the government (Komnas Perempuan, 2007, p. 36). Suhartoera interpretations of history continue to be taught to a new generation of school children. Ten years after the fall of the regime, the existing textbooks were more critical only of one aspect, i.e. the regime being undemocratic (Suharto was no longer the "father of development") and they discussed problems such as muting the press, ideological in- 
doctrination, corruption and the imprisonment of political opponents. They also no longer presented East Timor as a great "beneficiary of Indonesian generosity" (roads, schools and clinics), and sometimes even mentioned that not all Timorese agreed to "join" East Timor into Indonesia and conduct a guerrilla war (Johnson Tan, 2008).

Van Klinken points out that historical discourses studies in other post-authoritarian countries show that creating myths is too useful to simply be abandoned. It is much more likely that this effort will be redirected to new goals. In Indonesia, too, authoritarian national historiography is by no means dead. Suharto has been ousted, but not the central role of the army in newer national histories, nor the statist ideology that supports it (van Klinken, 2005, p. 237).

During the Reformasi period, scholars, state officials and history teachers were discussing what content should be included in history textbooks, but there is no question of developing any strategy for historical education. One of my interlocutors mentioned that in 1998, when he started high school in Jakarta, history lessons at his school were stopped for a year. Teachers did not want to use old textbooks; new ones were not yet written and published. Meanwhile, the new curriculum was not created, but on 19 October 1999, the Education Department issued a guide for teachers (Dirjen Pendidikan Dasar dan Menengah) on how to cope with the discrepancy between official and media accounts of history. The reason given for writing the guide was that uncertainty of teachers would end in "negative consequences for national togetherness" (van Klinken, 2005, p. 242).

Since 2006 the Education Department has developed the Education Unit Level Curriculum (Kurikulum Tingkat Satuan Pendidikan, KTSP). The positive point of the KTSP was that teachers can now decide for themselves which materials, books and methods to use in the classroom (Leksana, 2009, pp. 184-185). The problem, however, remained as to the content of the textbooks themselves. The issue of the death of thousands of people has been completely ignored in the debates about the new curriculum for teaching history. Clearly, there is no place for narrations other than the one that was in force during the regime.

While discussing the content of history textbooks, some scholars ${ }^{7}$ postulated to use the name used by the assassins themselves, i.e. G30S instead of G30S/PKI. Authors of some history textbooks actually use the name G30S, others use the "old" term by adding $\mathrm{PKI}$, i.e. G30/PKI ${ }^{8}$. All of them, however, consistently neglect the issue of mass bloody purges that occurred just after the attack, focusing on emphasising the rapid economic development that took place during the regime. The fact that in 1976 was published the Indonesian National History Textbook (Sejarah Nasional Indonesia) may offer some explanation. The Minister of Culture and Education noted that this work has become the standard for the textbooks on all education levels (Nilsson Hoadley, 2005, p. 5). Consisting of six volumes, it was the first comprehensive story written by Indonesians. All volumes of this historical series are still a reference point for current school textbooks (Leksana, 2009, pp. 180-181).

As a result, however, Indonesian public opinion is not really confronted with the truth, and the lack of government action to punish the perpetrators and make them accountable for the crimes, contributes to the deepening of injustices and divisions in society. The perpetrators find themselves in new, even more powerful roles. Until today, we observe a policy in Indonesia striving to support national identity by defining a well-known enemy, which is still communism. Any denial of this binding and unifying myth is still perceived

7 For example, Asvi Warman Adam from Indonesia's Institute of Sciences, LIPI.

8 For example, Supriatna and Urdin, 2007. 
by some political, ethnic and religious groups as a threat to national identity. This leads to constant discrimination against alleged communists and their descendants, in the name of the vaguely understood national unity and identity of civil society. In this way, social life is still shaped by oppressive institutions built on bloody violence and Suharto's historical policy. As van Klinken writes, "school history lessons, ignoring every other social, cultural or economic dynamic, turned the previous three centuries into one continuous struggle for the Indonesian state against an array of enemies-first the colonial Dutch, then internal enemies such as communists and separatists" (van Klinken, 2005, p. 234).

Thus, we have a situation in which there is a significant gap in Indonesian collective memory about facts of significant importance to society. Lack of victim's perspective in the official historical narrative and education causes misunderstanding for all activities related to reconciliation. Historical education is heavily dependent on many external parameters such as political and geopolitical stability, political culture, social stability and economic well-being. All these factors definitely shape the framework of educational and textbook reform. In Indonesia, it is easier to reform the conditions of economic prosperity and political stability, which is currently lacking in this country than historical education. In the conditions of constant transformation, liquidity and crisis, history acquires a certain compensatory character. Such periods are conducive to the policy of memory, which offers simplified and polarising historical exegesis and provides easy answers to complex phenomena. Then, historical education is a highly public and political issue (for more about the relationship between TJ and history education see Ramírez-Barat \& Duthie, 2017).

The education sector creates a multigenerational opportunity to deal with a difficult heritage. It includes not only students but also teachers who have to deal with violent legacy, myths and misinformation about the past. They, in this sense, also became victims of the past regime. Historical education faces a huge challenge as the one that has to satisfy the demands of many social groups. Depending on the historical policy pursued in the country, it can become an institution that further deepens injustices and divisions within society, but a "justice" institution can become just as well. Committees of truth and justice can go further in their activities, working with teachers and educators who are connecting with local communities, offering ready-made programs and didactic workshops to be carried out with students during lessons. In addition, it is not just a change in didactics, but a pedagogical change is needed, including pedagogical reform as a part of the comprehensive history of education reform (Cole \& Murphy, 2009). Davies proposes three mechanisms of justice-sensitive changes are outlined here: structural reforms, changes in curriculum and institutional culture (Davies, 2017). Obviously, this is impossible without a broader effort to provide a reconciliation process in which justice and respect are of paramount importance.

The current Indonesian pupils and students did not directly experience mass violence in past conflicts, were born long after them, but were too young to notice the transition to the days of peace. Young people inherit not only the dramatic legacy of the past, but the transitions themselves, their legacies and the legacies of the remedies too. Maintaining the previous version of events from 1965-66 in history textbooks is contrary to the basic social function of history, which is to shape critically thinking individuals who understand the present and are able to establish their own identity in a complex and often contradictory reality. School and university are places where a new generation can critically learn and learn about the difficult history of its own nation, but also about how to deal with it. 
Especially in such a multiethnic and multireligious society as the Indonesian one, where the peaceful coexistence and the Bhinneka Tunggal Ika ${ }^{9}$ motto are so important.

A number of NGOs supporting the policy of remembrance and the process of settling accounts with the past, try to meet government representatives in order to change the existing history in primary and higher education. Komnas Perempuan (National Commission on Violence Against Women), has already prepared in 2007 recommendations for the Indonesian government in the field of historical education:

The Government, especially the Department of Education, shall safeguard and support education on history, both formally and informally, which reflects the truth and reveals the experiences of women and children who were victims of the 1965 Tragedy. This education should be directed at the younger generation who need to know the truth about the violations that were committed and the impact on the victims. This education should encompass history about women's movements.

Indonesian Institute of Social History (Institut Sejarah Sosial Indonesia, ISSI, based in Jakarta) has been conducting a series of history discussions with students and working with history teachers since 2004 (Leksana, 2009, p. 177).

The activities of NGOs are also manifested in many other fields: from organising conferences, exhibitions, concerts and art shows, to actions in which the counter-remembrance of victims and survivors is heard (collecting testimonies of survivors). The countermemory delegitimises the power relations, where the victims of the regime play the role of subordinates and the repressed. As a result of this process, their voice in the discussion becomes as important as the official one (Assmann, 2011). But even today those who organise meetings or discussions on this subject may be refused permission to do so by local officials, or be harassed by local militia.

Interestingly, many of the activists are young people. In 1965, they were small children, or even were born after a period of the bloody political purge, and "recruit" of both families, the perpetrators and the victims. Post-65 generation is an implicated community (Morris-Suzuki, 2005). It is not directly responsible for the bloody past, but it is inseparably connected with it, shaped by it and will remain in it until it actively changes it:

We are also implicated in the past in a wider sense. We live enmeshed in structures, institutions and webs od ideas which are the product of history, formed by acts of imagination, courage, generosity, greed and brutality performed by previous generations. Often we are quite unconscious of the way in which these structures and ideas have come into being (MorrisSuzuki, 2005, p. 26).

Hirsch calls this specific type of memory post-memory, on the basis of which the subject builds its identity based on the content remembered and embedded in consciousness, but not from its own experience but rather from the experience of the older generation (Hirsch, 1997). This type of post-memory prompts the implicated community to take action to seek justice for the benefit of years of marginalised members of society. "Ingat 65" enables "writing history" to people who are hurt, witnesses to the events, family members or people who simply oppose to the concealment of truth about the circumstances in which the PKI is liquidated in historical politics. The motto "Ceritaku ceritamu cerita kita tentang 65" can be interpreted as "my story is your story, and together we create a story about '65". This sentence reflects well today's Indonesian reality, in which only in this way you can create counter-narratives about what happened to Indonesia in

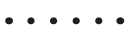

9 Unity in Diversity. This motto together with Pancasila principles form the basic national ideology of Indonesia. 
1965. The stories of "Ingat 65" are stories about exclusion and the excluded, built using alternative means. Their essence is memory, challenging the official historical narrative and the lack of perspective of victims in historical discourses. The Internet contributes to the fact that no longer the government has a monopoly on information.

\section{CONCLUSION}

In authoritarian and divided societies with identity-based conflicts, education has quite often been used as an instrument of inequality and division as well as a medium for spreading myths and misinformation, as observed in Indonesia. Active generation of the memory oblivion in the public space is not only ignoring silence, applying taboos, obliterating traces, but even negating the fact of mass murder. Historical education is often the last element in building the strategy of a new, stable state. We are slow to apply the same kind of rigorous reforms to this sector that we would do for the judiciary, military and police.

The consistent omission of the truth about the brutal past and its consequences, and the lack of action towards settlement with it, can only intensify tensions around the conflict, deepen misunderstandings and misperceptions that different groups of society have about each other and about themselves. It is a well-known fact that school history textbooks are key resources for shaping collective memory and strengthening social and national cohesion. They differ from other knowledge resources with regard to the knowledge they transmit being particularly durable and selective at the same time. Functioning as a platform for the dissemination of knowledge, they reflect the main social and national values and are a place where the national canon of history is customarily passed on to the public. But in the TJ process it is not just about the categorical and unambiguous statement of what is good and what is bad. Historical education is one of the most important tools for rethinking history, opening up space for many counter-memories, in which greater diversity of people can talk about their traumatic experiences, supporting the reconciliation between the victims and the national and local communities.

\section{BIBLIOGRAPHY}

Aritonang, M. S. (2017, January 18). Lack of applicable solutions hampers Jokowi's efforts to resolve past abuses: Official. The Jakarta Post. Retrieved June 7, 2018, from http://www.thejakartapost.com/news/2017/01/18/lack-of-applicable-solutions-hampers-jokowis-efforts-to-resolve-past-abuses-official.html

Assmann, A. (2011). Cultural memory and Western civilization: Functions, media, archives. Cambridge: Cambridge University Press. https://doi.org/10.1017/CBO9780511996306

Cole, E. A., \& Murphy, K. (2009). History education reform, transitional justice and the transformation of identities. ICTJ Research Brief. Retrieved June 7, 2018, from https:// www.ictj.org/sites/default/files/ICTJ-Identities-HistoryEducation-ResearchBrief-2009English.pdf

Cribb, R. (1990). Problems in the historiography of the killings in Indonesia. In R. Cribb (Ed.), The Indonesian killings of 1965-1966: Studies from Java and Bali (pp. 35-37). Clayton, Victoria: Monash University Centre of Southeast Asian Studies. (Monash Papers on Southeast Asia, 21). 
Cribb, R., \& Ford, M. (2010, January 24). The killings of 1965-66. Inside Indonesia, 2010(99: January-March). Retrieved June 7, 2018, from http://www.insideindonesia. org/the-killings-of-1965-66

Davies, L. (2017). Justice-sensitive education: The implications of transitional justice mechanisms for teaching and learning. Comparative Education, 53(3), 333-350. https:// doi.org/10.1080/03050068.2017.1317999

Fealy, G., \& McGregor, K. E. (2012). East Java and the role of Nahdlatul Ulama in the 1965-66 anti-Communist violence. In D. Kammen \& K. E. McGregor (Eds.), The contours of mass violence in Indonesia, 1965-68 (pp. 104-130). Singapore: NUS Press.

Głąb, K. M. (2017). Święte Muzeum Pancasila: Muzeum martyrologiczne budujące tożsamość narodu indonezyjskiego. Muzealnictwo, 2017(58), 188-194.

Heryanto, A. (1999). Where Communism never dies: Violence, trauma and narration in the last Cold War capitalist authoritarian state. International Journal of Cultural Studies, 2(2), 147-177. https://doi.org/10.1177/136787799900200201

Heryanto, A. (2006). State terrorism and political identity in Indonesia: Fatally belonging. London: Routledge.

Hirsch, M. (1997). Family frames: Photography, narrative, and postmemory. Cambridge, MA: Harvard University Press.

International People's Tribunal. (1965). Final Report of the IPT 1965. Findings and Documents of the International People's Tribunal on Crimes against Humanity Indonesia 1965, 20 July 2016. The Hague: IPT 1965 Foundation.

Johnson Tan, P. (2008, May 4). Teaching and remembering. Inside Indonesia, 2008(92: April-June). Retrieved June 7, 2018, from http://www.insideindonesia.org/teachingand-remembering

Karmini, N., \& Wright, S. (2016, April 18). Indonesia takes step toward reckoning with '6566 atrocities. The Washington Post. Retrieved August 19, 2017, from https://www. washingtonpost.com/world/asia_pacific/indonesia-takes-step-toward-reckoning-with65-66-atrocities/2016/04/18/6cbd2288-052f-11 e6-bfed-ef65dff5970d_story.html

van Klinken, G. (2005). The battle for history after Suharto. In M. S. Zurbuchen (Ed.), Beginnning to remember: The past in the Indonesian present (pp. 233-255). Singapore: Singapore University Press.

Komnas Perempuan. (2007). Women's human rights monitoring report gender-based crimes against humanity: Listening to the voices of women survivors of 1965. Jakarta: Komnas Perempuan. Retrieved June 7, 2018, from http://lib.ohchr.org/HRBodies/UPR/ Documents/session13/ID/Komnas_Perempuan_UPR_IDN_S13_2012_KomnasPerempuan_Annex8_E.pdf

Leksana, G. (2009). Reconciliation through history education: Reconstructing the social memory of the 1965-66 violence in Indonesia. In B. Brauchler (Ed.), Reconciling Indonesia: Grassroots agency for peace (pp. 175-191). New York, NY: Routledge.

McGregor, K. E. (2007). History in uniform: Military ideology and the construction of Indonesia's past. Honolulu: University of Hawai'i Press.

McGregor, K. E. (2012). Mass graves and memories of the 1965 Indonesian killings. In D. Kammen \& K. E. McGregor (Eds.), The contours of mass violence in Indonesia, 1965-68 (pp. 234-262). Singapore: NUS Press and NIAS Press.

Mardiyati, A. (2017). Kenangan sebuah propaganda. Retrieved June 7, 2018, from https:// medium.com/ingat-65/kenangan-sebuah-propaganda-16966ddec054

Melvin, J. (2016). Symposium on Indonesia's 1965 genocide opens Pandora's box. Retrieved June 7, 2018, from http://asiapacific.anu.edu.au/newmandala/2016/05/09/symposium-on-indonesias-1965-genocide-opens-pandoras-box/ 
Morris-Suzuki, T. (2005). The past within us: Media, memory, history. London: VERSO.

Nilsson Hoadley, A.-G. (2005). Indonesian literature vs new order orthodoxy: The aftermath of 1965-1966. Copenhagen: NIAS Press.

Oppenheimer, J. (Director). (2012). The Act of Killing [Jagal]. Norway-Denmark-United Kingdom: Final Cut for Real/DK.

Pohlman, A. E. (2013). Documentation: reports by human rights and victim advocacy organisations in Indonesia: Reconciling the violence of 1965. Journal of Current Southeast Asian Affairs, 32(3), 143-165.

Pohlman, A. E. (2016). A year of truth and the possibilities for reconciliation in Indonesia. Genocide Studies and Prevention, 10(1). https://doi.org/10.5038/1911-9933.10.1.1323

Ramírez-Barat, C., \& Duthie, R. (2017). Transitional justice and education: learning peace. New York, NY: International Center For Transitional Justice, UNICEF, Social Science Research Council. (Advancing transitional justice series, 7).

Robinson, G. (2017). Down to the very roots: The Indonesian army's role in the mass killings of 1965-66. Journal of Genocide Research, 19(4), 465-486. https://doi.org/10.108 0/14623528.2017.1393935

Roosa, J. (2006). Pretext for mass murder: The September 30th Movement and Suharto's coup d'état in Indonesia. Madison: The University of Wisconsin Press.

Roosa, J. (2010, January 24). Dictionary of a disaster. Inside Indonesia, 2010(99: JanuaryMarch). Retrieved June 7, 2018, from http://www.insideindonesia.org/dictionary-of-adisaster

Roosa, J., \& Oppenheimer, J. (2014). Interview with Joshua Oppenheimer. Rethinking History: The Journal of Theory and Practice, 18(3), 413-422. https://doi.org/10.1080/13 642529.2014.898422

Santoso, A., \& van Klinken, G. (2017). Genocide finally enters public discourse: The International People's Tribunal 1965. Journal of Genocide Research, 19(4), 594-608. https://doi.org/10.1080/14623528.2017.1393970

Schreiner, K. H. (2005). Histories of trauma and sites of memory. In M. S. Zurbuchen (Ed.), Beginnning to remember: The past in the Indonesian present (pp. 261-277). Singapore: Singapore University Press.

Simons, G. (2000). Indonesia: The long oppression. Basingstoke: Palgrave Macmillan UK. https://doi.org/10.1057/9780333982846

Supriatna, S., \& Urdin, M. (Eds.). (2007). Sejarah untuk Kelas XII SMA. Bandung: Grafindo Media Pratama.

Taylor, J. G. (2003). Indonesia: Peoples and histories. New Haven, CT: Yale University Press.

Topsfield, J., \& Rompies, K. (2016, April 18). Indonesia rules out apology to victims at state-endorsed talks on 1965 massacres. The Washington Post. Retrieved June 7 , 2018, from http://www.smh.com.au/world/indonesia-rules-out-apology-to-victims-atstateendorsed-talks-on-1965-massacres-20160418-go96fq.html

Vickers, A. (2005). A history of modern Indonesia. Cambridge: Cambridge University Press. https://doi.org/10.1017/CBO9780511801020

Wahyuningroem, S. L (2013). Seducing for truth and justice: Civil society initiatives for the 1965 mass violence in Indonesia. Journal of Current Southeast Asian Affairs, 32(3), 115-142.

Zurbuchen M. S. (2002). History, memory, and the "1965 Incident" in Indonesia, Asian Survey, Vol. 42, No. 4 (July/August), 564-581. 